\title{
Influence of Gender on Interest and Academic Achievement of Students in Integrated Science in Obio Akpor Local Government Area of Rivers State
}

\author{
Godpower-Echie Glory \\ Ihenko, Sopuruchi \\ Integrated Science Department, Ignatius Ajuru University of Education, \\ Port Harcourt, Rivers State, Nigeria
}

doi: 10.19044/esj.2017.v13n10p272 URL:http://dx.doi.org/10.19044/esj.2017.v13n10p272

\begin{abstract}
The study looked at the influence of gender on interest and achievement of integrated Science students in Obio Akpor local government area of Rivers State. Two research questions and two hypotheses were raised, the population comprised of all secondary school students in the local government area and a total of 600 students took part in the study. Two instruments were used to collect data: the test scores and a likert scale like interest scale. Mean, standard deviation and t-test were used to analyse the data. The findings showed that gender has a significant influence on the interest but does not have a significant influence on achievement of Integrated Science students. It was recommended: that Integrated Science teachers should teach in such a way as to rouse the interest of the students, students should be self motivated, find joy in learning in order to excel.
\end{abstract}

Keywords: Influence, gender, interest, achievement, science, Port Harcourt

\section{Introduction}

Several studies have been carried out over the years to determine factors that influence students' achievement in Integrated Science. Integrated Science is a fundamental science subject that prepares students for the senior secondary school science subjects and subsequently for science related courses in higher institutions. Abande (2010), opined that interest is a state of curiosity or concern about something or the attention given to something. Magnus (2008), further stated that interest encompasses the positive, pleasant feelings an individual has when trying to study a subject-matter. From the above definition, it could be concluded that interest governs our feeling and attitudes towards a particular thing or activity. Deci (1998) emphasized that interest is an important factor that supports learning, 
individual development and achievement. Gbamanja (1992) in Olatunde (2007), itemized problems that have to a great extent drastically reduced students' interest in integrated science hence their achievement in the subject; these problems include;

- $\quad$ Lack of understanding of what science is all about.

- $\quad$ Lack of well equipped science laboratory

- Lack of funds for the supply and maintenance of necessary equipment.

- $\quad$ Poor teaching strategies used by the teachers.

- $\quad$ Lack of workshop centres.

- $\quad$ Lack of textbooks, journals and materials needed for professional growth.

If a student shows a higher interest in a course, this will help him to put in more time, effort and energy in learning which will in turn lead to higher or better achievement. In a research by Olaf, Jurgen \& Kai (2010) involving 602 students in Germany, they found out sex differences in achievement in favour of boys in mathematics achievement, they also found out that interest had no significant effect on learning from grade 7 to grade 10 but affected their course selection. Further it was seen that interest at the end of grade 10 had a direct and indirect effect (via course selection) or achievement in upper secondary school. This means that high achievers showed more interest than low achievers. Allen and Robbins (2010) tested the effects of interest and motivation on timely degree completion they found out that interest had a direct effect on timely completion while motivation had an indirect effect. These findings show the importance of interest on students' achievement.

Jegede (1990) in a survey of junior school boys and girls on the influence of gender on interest in science argued that there is a gender gap concerning students' interest and achievement in science. Both male and female students perform well in science in the junior secondary school but by the time they begin their course of study in the polytechnics and universities the female students do not retain their interest in science.

Further, in Azman (2014), according to a survey carried out in selected educational institutions in Sub-Saharan Africa, the issue of gender played a major role in the choices students made and also their performances in core science subjects.

Umoh (2003) conceptualized gender as a psychological term used in describing behaviours and attribute expected of individuals on the basis of being born as either male or female. Wonu \& Anackwe (2014) found out no significant difference in the mathematic achievement of male and female 
students. Josiah \& Etuk-Iren also found out a non significant relationship between gender and achievement of college students.

Abiam \& Odok (2006) in their research work found that there was no significant gender difference in the achievement of students in number; numeration statistics and algebraic process. In a similar vein Josiah \& EtukIren (2014) found a non significant relationship between gender, age, mathematics anxiety and college students' achievement in algebra

In another research by Mari and Shauba (1997), they revealed that female students had a better understanding of science process skills when compared to the male students. They suggested that the view that seems to have established itself that boys are better than girls in science education needs to be approached and interpreted with great caution. Similarly, Godpower-Echie and Amadi (2013) in a research work involving four hundred (400) senior secondary (SS) 2 chemistry students found out that there was a positive correlation between gender and students' achievement in chemistry. Females tend to perform better in areas of standardized science assessment that address the human application of science such as life science, (Ingels and Dalton, 2008). Contrary to the findings above, Babalola and Fayombo (2009), found out that there was no statistically significant difference in the students' science achievement based on gender. Fredrick (2008) opines that there was no statistical difference between boys and girls in the ability to manipulate the apparatus/equipment take observations, report/record results correctly, and compute/interpret/analyse result during chemistry practicals and that both male and female students perceived interpreting/analysing results to be most difficult skill to perform during chemistry practical. Ikenna (2009), found out that gender alone has no effect on academic achievement but could act in conjunction with other variables to affect learning outcomes.

Therefore an investigation into the influence of gender on interest and achievement of students in integrated science in Obio/Akpor Local Government Area of Rivers State is timely and worthwhile.

\section{Research questions:}

1. What influence does gender have on students' interest in integrated science?

2. What influence does gender have on students' achievement in Integrated Science?

\section{Hypotheses}

1. Gender does not have any significant influence on students' interest in Integrated Science. 
2. Gender does not have any significant influence on students' achievement in Integrated Science.

\section{Methodology}

\section{Research design}

The researcher adopted the descriptive survey research design. According to Nwankwo (2013), the thrust in the use of this design is that certain features or variables are merely described as they are at that particular time.

\section{Population}

The population of the study was all the junior secondary schools students in Obio/Akpor (private and government) from which a total of ten schools 5 private 5 public were selected.

\section{Sample and sampling technique}

Stratified random sampling technique was used to sample a total of 600 students. 250 female and 350 male students took part in the study from ten secondary schools in Obio/Akpor Local Government.

\section{Instrument for data collection}

Two instruments were used; test scores and a likert like scale interest inventory to measure the level of the students' interest towards Integrated Science.

\section{Procedure for data collection}

Test scores of the students were collected from the various schools, the interest inventory was given to the students to indicate their level of interest in integrated science.

\section{Method of data analysis}

Mean, standard, deviation and t-test were used to analyse the data collected.

\section{Results}

Research Question 1: What influence does gender have or students' interest in Integrated Science?

Table 1: Mean, Standard Deviation on the influence of gender on students' interest.

\begin{tabular}{|c|c|c|c|c|}
\hline Gender & $\mathrm{N}$ & $\bar{x}$ & SD & Evaluation Remark \\
\hline Female & 250 & 31.44 & 4.30 & Good \\
\hline Male & 350 & 32.63 & 4.20 & Good \\
\hline
\end{tabular}


Table 1 showed that the mean interest of the male (32.63) and female (31.44) students were almost the same. It could be said that the interest of students in Integrated Science was good.

Hypothesis 1: Gender does not have any significant influence on students' interest in Integrated Science.

Table 2: T-test analysis of the difference between male and female students' interest in Integrated Science.

\begin{tabular}{|c|c|c|c|c|c|c|c|}
\hline Gender & $\mathrm{N}$ & $\bar{x}$ & $\mathrm{SD}$ & $\mathrm{df}$ & t-cal & t-crit & Result \\
\cline { 1 - 4 } Female & 250 & 31.44 & 4.30 & \multirow{2}{*}{598} & 3.40 & \multirow{2}{*}{1.960} & $\mathrm{~S}$ \\
\hline Male & 350 & 32.63 & 4.20 & 598 & \\
\hline
\end{tabular}

From table 2 showing t-cal as (3.40), > t-crit (1.960) at the $\mathrm{df}$ of 598 and 0.05 level of significance, the null hypothesis is rejected. The result is that gender has significant influence on students' interest in Integrated Science.

\section{Research Question 2:}

What influence does gender have on students' achievement in Integrated Science?

\begin{tabular}{|c|c|c|c|c|}
\hline Gender & $\mathrm{N}$ & $\bar{x}$ & SD & Evaluation Remark \\
\hline Female & 250 & 52.05 & 11.82 & Good \\
\hline Male & 350 & 53.52 & 10.55 & Good \\
\hline
\end{tabular}

Table 3 showed that the mean achievement of the male at 53.52 and female at 52.05 were almost the same. There is just a slight difference.

Hypotheses 2: Gender does not have any significant influence on students' achievement.

Table 4: standard deviation and t-test analysis of the difference between male and female students achievement in integrated science.

\begin{tabular}{|c|c|c|c|c|c|c|c|}
\hline Gender & $\mathrm{N}$ & $\bar{x}$ & $\mathrm{SD}$ & $\mathrm{df}$ & $\mathrm{t}$-cal & t-crit & Result \\
\hline Female & 250 & 52.05 & 11.82 & \multirow{2}{*}{598} & & & \\
\cline { 1 - 5 } Male & 350 & 53.52 & 10.55 & & & \\
\hline
\end{tabular}

From the table above since t-cal (1.574) < than t-crit (1.960) at the $\mathrm{df}$ of 598 and 0.05 level of significance the null hypothesis is accepted. The result is that gender does not have a significant influence on students' achievement in Integrated Science.

\section{Discussion}

Table 1 showed that the mean interest score of male and female students in Integrated Science was almost the same. Table 2 showed that gender has significant influence on students' interest in Integrated Science. This is in agreement with the work of Ugorji (2001), who argued that there 
was a gender gap concerning students' interest in science. Also as seen in Temitope (2011), due to African culture and traditions, males are more inclined towards the sciences while females tend to tilt more to the arts. Table 3 showed a very slight difference in the achievement of male and female students while Table 4 showed that gender has no significant influence on students' achievement. This is in agreement with the work carried out by Babalola and Fayombo (2009), Adenyi (1999) \& Richman (2014) where they found out that there was no statistical significant difference in student achievements based on gender, but inconsistent with findings by Mari \& Shauba (1997), Ibiri (2012), Godpower-Echie \& Amadi (2013) who indicated that there is a positive correlation between gender and students’ achievement.

\section{Conclusion and recommendations}

The work looked into the influence of gender on the interest and academic achievement of students in Integrated Science in Obio Akpor local government area of Rivers State. It was found out that gender has a significant influence on the interest of students in Integrated Science, but does not have any influence on students' achievement. Based on this, the following recommendations were made:

1. Teachers of Integrated Science should teach in such a way as to rouse students' interest in the subject, science should be real to the students.

2. Parents should not segregate in terms of the education of their children.

3. Children should be encouraged and provided with their essential needs to make learning a thing of interest to them.

4. Students should motivate themselves, find joy in learning, they should not wait to be pushed by their parents and teachers before they can learn and achieve.

\section{References:}

1. Abande, G.K. (2010). Pedagogical Learning Techniques in the $21^{\text {st }}$ Century. Ibadan: Mind Press Ltd.

2. Abiam, P.O. \& Odok, J.K. (2006). Factors in students' achievement in different branches of secondary school mathematics. Journal of Education and Technology, 1 (1) 161-168.

3. Azman (2014). Constraints and Remedies to Students Dread for the Sciences. Scientific Journal of Educational Administrators. 3(8) 9-19.

4. Adeniyi, I.A. (1999). A path analytic study of some teacher characteristics and teacher job performance in secondary schools in Ogun State, Nigeria. Unpublished Ph.D Thesis University of Ibadan, Ibadan. 
5. Allen, J. \& Robbins, S. (2010). Effect of interest - major congruence, motivation and academic performance on timely degree attainment. Journal of Couns Psychol 2010 57(1) 23-35.

6. Babalola J.O. and Fayombo, G.A. (2009). Investigating the combined and relative effects of some student related variables on science achievement among secondary school students in Barbados: European Journal of Scientific Research 37 (3) 481 - 489.

7. Deci, E. (1998). Relationship of interest and motivation. Proceedings of $2^{\text {nd }}$ conference on interest and gender. IPN 164: 146-162.

8. Fredrick, S. (2008). Gender differences in performance of chemistry practical skills among senior six students in Kampala District Bola Raton Florida.

9. Gbamanja, S.P.T. (1992). Teaching Integrated science Effectively. Port Harcourt: Palm Unique Publishers.

10. Godpower-Echie, G. \& Amadi, J. (2013). Attitude and gender differences on students' achievement in Chemistry. New Era Research Journal of Human Educational and Sustainable Development, 6 (3) 64-68.

11. Houghton Miffin (2000). The American Heritage Dictionary of English language. $4^{\text {th }}$ edition. Houghton Miffin company.

12. Ibiri, T.I. (2012). Influence of Cultural Differences on the Educational Choices of Students in Modern Times. Journal of Modern Educational Advancements. 3 (5) 16-21.

13. Ingels, S.J. \& Dalton B.W. (n.d). Trends Among High School Seniors. California: Huntington Beach.

14. Jegede, O. (1990). The effect of laboratory and lecture methods on cognitive achievement. Integrated Science Journal of research in science and technology, $321-5$.

15. Josiah, O. \& Etuk-Iren, O.A. (2014). Effect of gender, age and mathematics anxiety on college students. Achievement in Algebra. American Journal of Educational Research, 2 (7) 474-476.

16. Magnus, K.O. (2008). Re-positioning Science Education for the African Child. Asaba: Omega Publishers.

17. Mari J.S. \& Shauba, A.M. (1997). Gender related differences in the understanding of science process skills. Journal of Science Teachers Association of Nigeria 32: $21-27$

18. Olaf, K. Jurgen, B. \& Kai, S. (2010). Does interest matter? The relationship between academic interest and achievement in mathematics. Journal of Research in Mathematics Education, 32 (5) 448-470. 
19. Olatunde, W.V. (2007). Problems and Remedies to the advancement of science education in nigeria. Journal of educational development 5(9), 15-21.

20. Richman, E.I. (2014). Career Guide for the Young School Leaver. Mbaise: Hero Publishers

21. Temitope, P.R. (2011). The Role of ICT in aiding Students Comprehension of Science-based Courses in South-West Nigeria. Journal of Advanced Educational Administration and Planning. 2(1) 13-20

22. Ugorji, O. (2001). Interest and its effect on students achievement in science-based subjects. Journal of Research Planning 3(4), 22-29.

23. Umoh, C.A. (2003). A theoretical analysis of the effects of gender and family education on human resource development. Journal of Curriculum Organization of Nigeria, 10 (1) 1-4.

24. Wonu, N. \& Anaekwe, E. (2014). School effect on students' mathematical achievement in Obio/Akpor Local Government Area of Rivers State. International Journal of Educational Development, 4 (1) 69-77. 